\title{
Variability of Transferrin in Field Mouse from Urban and Suburban Populations ${ }^{1}$
}

\author{
Anna DOBROWOLSKA, Ewa JABEOŃSKA, Anna PATRZYKONT \\ \& Elżbieta CHABROS
}

\begin{abstract}
Dobrowolska A., Jabłońska E., Patrzykont A. \& Chabros E., 1983; Variability of transferrin in field mouse from urban and suburban populations. Acta theriol., 28, 15: 235-242 [With 2 Tables]

On the basis of 3-year studies of transferrin polymorphism in Apodemus agrarius in chosen differently isolated urban (Warsaw), suburban and field (Turew) populations it was stated as follows: (a) a lack of differences in variability of transferrin related to sex, sexual activity and season (summer - early autumn), (b) differences in frequencies of transferrin alleles between populations during two years of studies when gradient of genetic variability in populations was opposite to gradient of isolation and urbanization of habitat studied, (c) significantly different frequencies of transferrin alleles from year to year in isolated population from the city centre. The smaller variability, greater differentiation in time and non-random distribution of genotypes in isolated population from city centre might confirm specific structure of this population as stated in ecological studies.

[Dept. Vertebr. Anim. Physiol., Inst. of Zool., Univ. of Warsaw, Z wirki i Wigury 93, 02-089 Warszawa, Poland]
\end{abstract}

\section{INTRODUCTION}

One of the most interesting ecological phenomenon is an expansion of typical field rodent - the field mouse Apodemus agrarius (Pallas, 1771) towards urban environments. The occurrence of this mouse in majority of green areas of Warsaw, even in those situated in the central part of the city, points out highly advanced process of synurbization of this species. Sumiński (1922) reported the first information on A. agrarius inhabiting Warsaw. Observations of fauna of Warsaw made by Wałecki, originated from the end of XIX century (1881) did not contain the informations on the occurrence of this rodent. It might be supposed that this species survived in enclaves of green areas situated now in the centre of city, adaptating itself to changed conditions and also imigrated towards the centre from areas placed around Warsaw.

It appeared interesting to study the genetical differentiation of A. agrarius populations, which might be one of the indices of ecological

1 Praca wykonana w ramach problemu MR.II.6, koordynowanego przez Zakład Paleobiologii PAN. 
phenomenon occurring in urban and field populations of this species. Joining the complex ecological investigations realised by Andrzejewski et al. (1978) it was resolved to estimate and compare the polymorphism of transferrin in field mouse populations living in the chosen less or more isolated urban parks of Warsaw, as well as suburban areas and in fields.

\section{MATERIAL AND METHODS}

The urban areas studied were the old parks placed in the centre of Warsaw (Botanical Garden) and out of the city centre (Greek Orthodox Cemetery surrounded by the streets of extremely big traffic as well as by close urban houses. The differentiated vegetation with the majority of old trees (more than 80 year old) and bushes characterized these areas. The rodents were the majority of the animals inhabiting these areas. A. agrarius reached a great number there probably as a result of a lack of competition from other rodent groups and great number of shelters (Andrzejewski et al., 1978; Babińska et al., 1979).

The chosen suburban areas placed far away from the centre were the Bielany Grove and Młociny Wood. Adjoining to Vistula river and placed north from the centre they were not such enclosed enclaves and, moreover, they were not such frequently visited by people as the first two habitats (Botanical Garden and Greek Orthodox Cemetery). The number of populations on these areas were not such a great as in populations from isolated urban places.

Exact description of study areas as well as characteristics of populations studied are in papers by Andrzejewski et al. (1978), Babińska-Werka et al. (1979) and Goszczyński (1979).

The chosen non-urban areas were: (a) The island placed on Beldany Lake (Masurian Region) of 4 ha in surface, with differentiated vegetation (trees and bushes). Field mouse was introduced there in spring of 1974 from urban park in Warsaw (Botanical Garden), (b) the surroudings of Turew village (Leszno voivodeship) where the majority of the areas were composed with farmland and interfield afforestation occurring as a parks and clumps making up to 20 per cent of surface. Population of A. agrarius inhabiting this area had the possibility of migration. Field mouse caught on the border of fields and interfield afforestations can be considered inhabiting the most typical habitat to it.

The mice were caught in summer (June) and in early autumn (September) during 3 years (1975-1977), by means of live-traps empted each morning. The mice were weight and the blood was taken from retroorbital plexus under ether anaesthesia. The animals were dissected afterwards to determine their reproductive condition.

The blood serum was stored at $-20^{\circ} \mathrm{C}$ until analysis, then separated by means of starch gel electrophoresis in conditions described by Tomaszewska-Guszkiewicz et al. (1971) with boric acid- $\mathrm{NaOH}$ buffer $(\mathrm{pH}=8.6)$ as the solution for electrode trays and Tris-citric acid buffer $(\mathrm{pH}=7.6)$ as gel buffer. For identification of transferrin the Mueller's et al. (1967) method (iron specific staining) was used, than the gels were routinely stained with Amido Black 10B.

The transferrin fractions obtained were designed as $a, b$ and $c$ according to 
nomenclature of transferrin variants used for laboratory mice (Cohen \& Shreffler, 1961). On the basis of the number and the manner of placing of this fractions the following transferrin phenotypes were distinguished - phenotype I composed of $a$ and $b$ bands, phenotype II possessing bands $-a, b$ and $c$ and phenotype III composed of $c$ band.

Electrophoretic pattern of phenotypes obtained was presented by Dobrowolska \& Chabros (1978). Two phenotype Trf-ab predominated in populations instead of three band $T r f-a b c$ and phenotype $c$ band $T r f-c$ which occurred very rarely (two times in populations studied). The typical way of transferrin inheritance for mice (Rasmussen \& Koehn, 1966: Biggers \& Dawson, 1971 - the system of two alleles in one locus was proved taking the phenotype $I-\operatorname{Trf}-a b$ as an expression of one of homozygote $T r f^{a / b} / T r f^{a / b}$ and phenotypes II $T r f-a b c-$ as a heterozygous $\operatorname{Tr} f^{a / b} / \operatorname{Trf}^{c}$ with fraction $b$ in two cases accompained by fraction $a$ and phenotype III $\operatorname{Trf}-c$ as homozygous $\operatorname{Trf} \mathrm{C}^{\mathrm{T}} \operatorname{Trf}^{\mathrm{c}}$.

The statystical analysis of the results was made with chi-square - test used by Gaines \& Krebs (1971) accepting the differences as statistically significant $(S)$ at $p<0.05$.

Table 1

Frequencies of transferrin alleles in Apodemus agrarius from different urban and suburban and field populations (sample size - in parentheses).

\begin{tabular}{|c|c|c|c|c|}
\hline \multirow[b]{2}{*}{ Study area } & 1975 & 1976 & 1977 & \multirow{2}{*}{$\begin{array}{l}\text { Chi- } \\
\text { square }\end{array}$} \\
\hline & $\operatorname{Trf} a / b \quad \operatorname{Tr} f^{c}$ & $\operatorname{Trfa/b} \quad \operatorname{Trf} c$ & $\operatorname{Trfalb} \quad \operatorname{Tr} f^{c}$ & \\
\hline Botanical Garden & $\begin{array}{c}0.966{ }_{(75)}^{0.034} \\
\end{array}$ & $\begin{array}{c}0.973{ }_{(73)} \\
0.027\end{array}$ & $\begin{array}{c}0.796 \\
(54)\end{array}$ & $12.94^{1}$ \\
\hline $\begin{array}{l}\text { Greek Orthodox } \\
\text { Cemetery }\end{array}$ & - & - & $\begin{array}{c}0.884 \\
(69)\end{array}$ & - \\
\hline Bielany Grove & $\begin{array}{c}0.920 \quad 0.080 \\
(50)\end{array}$ & $\begin{array}{c}0.916{ }_{(77)}^{0.084} \\
\end{array}$ & - & 1.76 \\
\hline Młociny Wood & $\begin{array}{c}0.958 \quad 0.042 \\
(24)\end{array}$ & ${ }_{(68)}^{0.919} 0.081$ & - & 1.34 \\
\hline Turew fields & - & ${ }_{(18)}^{0.862} 0.138$ & $\begin{array}{c}0.895 \\
(62)\end{array}$ & 1.05 \\
\hline The Island & $\begin{array}{c}1.000 \quad 0 \\
(23)\end{array}$ & & & \\
\hline
\end{tabular}

${ }^{1} p<0.01$

\section{RESULTS}

Distribution of transferrin genotypes obtained agreed with HardyWeinberg equilibrium in all periods studied only in less isolated suburban parks (Bielany and Młociny) and natural fields (Turew). One of the investigated groups of rodents from Botanical Garden was not in agreement with expected ratio because of the majority of heterozygotes (autumn 1977, $\chi^{2}=6.41$, d.f. $=1, p<0.025$ ) and in other group 
the ratio was close to nonpanmictic distribution with almost significant deficiency of heterozygotes (spring $1976, \chi^{2}=3.0$, d.f. $=1, p<0.10$ ). In one case this population was monomorphic for $\operatorname{Tr} f^{a / b}$ allele. This analysis might indicate non-random, drifting character of isolated population from the city centre.

Since the significant differences in allele frequencies between females and males as well as differences related to the sexual activity and season.were not stated, the material from particular area caught in one year was taken together, then a different degree of transferrin polymorphism in dependence on studied areas was noted (Table 1,2). Population introduced to the island being the progeny of mice from Botanical Garden was monomorphic for $\operatorname{Trf}^{a / b}$ allele, while the rare $\operatorname{Tr} f^{c}$ allele did not occur there. The frequencies of the rare $\operatorname{Tr} f^{c}$ for

\section{Table 2}

Comparison of transferrin allele frequencies in group of Apodemus agrarius from different urban, suburban and field populations.

\begin{tabular}{lc}
\hline \multicolumn{1}{c}{ Compared areas } & Chi-square \\
\hline 1975 & \\
Botanical Garden - Bielany Grove & $5.29^{2}$ \\
Botanical Garden - Młociny Wood & 1.46 \\
Botanical Garden - The island & 0.01 \\
Bielany Grove - The island & $4.43^{1}$ \\
Miłociny Wood - The island & $4.26^{1}$ \\
1976 & \\
Botanical Garden - Bielany Grove & 3.08 \\
Botanical Garden - Młociny Wood & $8.86^{3}$ \\
Botanical Garden - Turew fields & $7.75^{3}$ \\
Bielany Grove - Turew fields & 2.54 \\
Młociny Wood - Turew fields & 1.11 \\
1977 & \\
Botanical Garden - Orthodox Cem. & $4.38^{1}$ \\
Botanical Garden - Turew fields & $4.23^{1}$ \\
\hline
\end{tabular}

${ }^{1} p<0.05,{ }^{2} p<0.025,{ }^{3} p<0.01$.

Turew field natural population were $0.138-0.105$ and were the closest to frequencies observed in natural populations living on farmland as pasture-mixture and winter-corn field (for males - 0.166 and for females - 0.192; Dobrowolska \& Zajączkowski, 1983).

The significantly lower frequencies of rare $\operatorname{Trf}^{\mathrm{c}}$ allele were observed in groups of individuals caught in 1975 and 1976 from isolated population in the city centre (Botanical Garden) than in those caught in the less isolated urban parks and placed far from the centre (Bielany and Młociny) and also in those caught in control, non-isolated population in Turew. The distribution of the allele frequencies was different 
in groups of individuals caught in 1977 than in those from following years. Frequency of rare allele $\operatorname{Trf}^{c}$ was the highest in group of individuals from Botanical Garden as compared with that caught in the other isolated urban area (Greek Orthodox Cemetery) and in field population from Turew (differences $S$ ).

Comparing the transferrin allele frequencies in successive years the statistically significant differences were observed only in mice from isolated urban areas (Botanical Garden). The allele frequencies in successive years were similar to each other on other areas studied (Bielany Grove, Młociny Wood, Turew fields).

\section{DISCUSSION}

The interdependence between frequency of occurrence of transferrin variations and physiological parameters like sexual activity and somatic puberty in many natural populations of small rodent, especially in voles was noted (Tamarin \& Krebs, 1969; Gaines \& Krebs, 1971). A lack of differences in the degree of transferrin polymorphism due to sex and physiological status is not an exception in field mouse. It was also found in many species of mice e.g. Peromyscus maniculatus (Rasmussen \& Koehn, 196), Apodemus sylvaticus (Pantalouris \& Arnason, 1967), Peromyscus polionotus (Biggers \& Dawson, 1971) and Mus musculus (Berry \& Murphy, 1970). It may be assumpted that the proteins studied can not have a selective significance in field mouse as in voles.

It seems to be interesting the fact that the isolated population from the city centre (Botanical Garden) was less differentiated (lower frequencies of rare $\operatorname{Trf} f^{c}$ allele) for the two successive years of study than populations living far from the city centre and in the country. Similarily Liro (1978) investigating the same individuals as described in this paper found small individual variation in morphophysiological parameters (direct and relative weight of organs) in the population living in the more isolated areas. So the gradient of variability in the two parameters studied was opposite to the gradient of environmental isolation and numbers of A. agrarius (Andrzejewski et al., 1978: Babinska-Werka et al., 1979).

It seems that above statement can not be, however, the general conclusion characterizing the urban population studied. The results obtained in the last year of study (1977) testified it. The previously less variable population from Botanical Graden showed in that year the higher variability (the highest frequency in rare $\operatorname{Trf}^{c}$ allele). Berry \& Murphy (1970) investigating island population of Mus musculus found 
that the population was monomorphic in one year while in the next the transferrin locus was differentiated. It can be suggested therefore that a group of mice living in isolated population may be subjected to greater selective pression of environment and differentiating the group into observed degree of polymorphism. This different variation observed from year to year may indicate the greater "plasticity" of the population and its greater ability to adaptation.

Many autors studying populations of voles and mice underlined the fact that an isolated population (island population, enclosed population) might reach a great numbers (Krebs \& Myers, 1974; Lidicker, 1973; Tamarin, 1978: Petrusewicz, 1978) and its specific spatial organisation and the behaviour of particular individuals played an important role in genetical structure of the species and making it mozaic in space and time (Rasmussen, 1970; Anderson, 1970; Myers, 1974; Lidicker, 1973). Differences in variability in genetical marker used, might relatively testify the differentiated spatial structure and generally the greater variability within time in the population.

According to ecological studies made by Andrzejewski et al. (1978) and Gliwicz (1980) synurbization of A. agrarius depends on the penetration of the green areas in the town and using differentiated natural and artificial shelters by this species. A lack of competition from the other rodents (Goszczyński, 1979; Andrzejewski et al., 1978) as well as smaller number of potential predators in urban parks (Goszczyński, 1979) forms the new interpopulationary conditions and cause probably the specific distribution of mice in urban parks. The aggregations noted on these areas (Andrzejewski et al., 1978) might cause the driftic pattern in part of population studied. The monomorphism in the part of population (the isolated population from the city centre and its progeny generation taken from island area) and a lack of random distribution of genotypes may be the result of this agregation or contrary - the monomorphic agregations may be formed by individuals of similar genotypes.

The pattern of variability in transferrin obtained in field mouse popopulations living in urban and suburban environments confirms the differences in structure and organisation of field mouse populations reported by ecologists.

Acknowledgements: We are very grateful to Professor R. Andrzejewski to enable us the Apodemus agrarius studies. We should like to express our since thanks to Professor K. Petrusewicz, Professor A. Andrzejewski, Professor J. Gill, Dr. J. Babińska-Werka and Dr J. Goszczyński for their criticism and for reviewing the manuscript!' We also indebted to $\mathrm{Mr} \mathrm{P}$. Muszyński for his help in English translation. 


\section{REFERENCES}

1. Anderson R. K., 1970: Ecological structure and gene flow in small mammals. Symp. zool. Soc. Lond, 26: 299-325.

2. Andrzejewski R., Babińska-Werka J., Gliwicz J. \& Goszczyński J., 1978: Synurbization processes in Apodemus agrarius population. I - Characteristics of populations in urbanization gradient. Acta theriol., 23: 341-358.

3. Babińska-Werka J., Gliwicz J. \& Goszczyński J., 1979: Synurbization processes in a population of Apodemus agrarius. II - Habitats of the striped field mouse in town. Acta theriol., 24: 22-31.

4. Berry R. J. \& Murphy H. M., 1970: The biochemical genetics of an island population of the house mouse. Proc. Roy. Soc. Lond. B, 176: 87-103.

5. Biggers Ch. J. \& Dawson W. D., 1971: Serum protein polymorphism in Peromyscus of South Carolina. J. Mammal., 52: 376-385.

6. Cohen B. C. \& Shreffler D. C., 1961: A revised nomenclature for the mouse transferrin locus. Gen. Res., 2: 306-308.

7. Dobrowolska A. \& Chabros E., 1978: Serum proteins of Apodemus agrarius (Pall. 1785) from different urban environments. Bull. Acad. pol. Sci., Cl. II, Ser. Sci., biol., 26: 337-342.

8. Dobrowolska A. \& Zajączkowski M., 1983: Variability of transferrin in three species of rodent populations coexisting in farmland. Acta theriol., 28: 225-233

9. Gaines M. S. \& Krebs Ch. J., 1971: Genetic changes in fluctuating vole populations. Evolution, 25: 702-723.

10. Gliwicz J., 1980: Ekologiczny aspekt synurbizacji myszy polnej Apodemus agrarius (Pall.). Wiad. ekol., 26: 117-124.

11. Goszczyński J., 1978: Penetration of mammals over urban green spaces in Warsaw. Acta theriol., 24: 417-419.

12. Goszczyński J., 1979: Density estimation for an urban population of the field mouse. Acta theriol., 24: 419-427.

13. Krebs Ch. J. \& Myers J., 1974: Population cycles in small mammals [In: "Advances in ecological research", Ed. A. Macfadyen ]. Academic Press, 8: 267-399. London, New York.

14. Lidicker W. Z. Jr, 1973: Regulation of numbers in an island population of the California vole and problem in community dynamics. Ecol. Monogr., 43: $231-302$.

15. Liro A., 1978: Morfofizjologiczne wskaźniki stanu populacji Apodemus agrarius (Pall. 1771) w Warszawie. Ph. D. Thesis, University of Warsaw.

16. Mueller J. O., Smithies O. \& Irvin P. R., 1962: Transferrin variation in Columbidae. Genetics, 43: 1385-1392.

17. Myers J. H., 1974: Genetic and social structure of feral house mouse populations on Grizzly Island, California. Ecology, 55: 747-759.

18. Pantalouris E. M. \& Arnason A., 1967: Serum proteins of Apodemus sylvaticus and Mus musculus. Comp. Biochem. Physiol., 21: 533-539.

19. Petrusewicz K., 1978: Osobnik, populacja, gatunek. Państw. Wyd. Nauk.: 1-384. Warszawa.

20. Rasmussen D. J., 1970: Biochemical polymorphism and genetic structure in population of Peromyscus. Symp. zool. Soc. Lond., 26: 335-349.

21. Rasmussen D. J. \& Koehn R. K., 1966: Serum transferrin polymorphism in the deer mouse. Genetics, 54: 1352-1357.

22. Sumiński S. M., 1922: Fauna Warszawy. Ziemia, 7: 328-335. 
23. Tamarin P. H. \& Krebs Ch. J., 1969: Microtus population biology. II. Genetic changes at the transferrin locus in fluctuating populations of two vole species. Evolution, 23: 183-211.

24. Tamarin P. H., 1978: Dispersal population regulation and $K$-selection in the field mice. Amer. Natur., 112: 545-555.

25. Tomaszewska-Guszkiewicz K., Składanowska E. \& Zurkowski M., 1971: Badania nad polimorfizmem amylazy krwi bydła nizinnego czarno-białego w Polsce. Biul. Inst. Genetyki i Hodowli Zwierząt PAN, 24: 5-10.

26. Wałecki A., 1881: Fauna zwierząt ssących Warszawy i jej stosunek do fauny całego kraju. Pam. Fizjograf., 1: 226-291.

Accepted, December 9, 1982.

\section{Anna DOBROWOLSKA, Ewa JABEONSKA, Anna PATRZYKONT i Elżbieta CHABROS}

\section{ZMIENNOSC TRANSFERYNY U MYSZY POLNEJ \\ Z MIEJSKICH I POZAMIEJSKICH POPULACJI}

\section{Streszczenie}

Na podstawie trzyletnich badań polimorfizmu transferyny surowicy krwi myszy polnych Apodemus agrarius z wybranych, mniej lub bardziej izolowanych populacji miejskich (Warszawa), pozamiejskich i polnych (Turew) stwierdzono: (a) brak różnic w zmienności transferyn związanych $\mathrm{z}$ płcią, stanem aktywności płciowej i sezonem (lato-wczesna jesień), (b) różnice w częstości alleli transferyny między populacjami podczas dwóch lat badań kiedy to gradient genetycznej zmienności populacji był odwrotny do gradientu izolacji i urbanizacji badanego siedliska, (c) istotnie różną częstość alleli transferyny $\mathrm{z}$ roku na rok $\mathrm{w}$ izolowanej populacji $\mathrm{z}$ centrum miasta.

Mniejsza zmienność, większe zróżnicowanie w czasie i nieprzypadkowy rozkład genotypów w izolowanej populacji z centrum miasta może potwierdzać specyficzną mozaikową strukturę tej populacji stwierdzoną w badaniach ekologicznych. 